TAPROBANICA, ISSN 1800-427X. May, 2020. Vol. 09, No. 01: pp. 23-30, pls. 9-11. (C) Research Center for Climate Change, University of Indonesia, Depok, Indonesia www.taprobanica.org

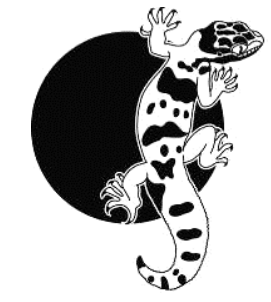

\title{
A NEW SPECIES OF Lankascincus GREER, 1991 (REPTILIA: SCINCIDAE) FROM THE RAKWANA HILLS OF SRI LANKA
}

\section{L.J. Mendis Wickramasinghe ${ }^{1,3}$, Dulan Ranga Vidanapathirana ${ }^{1} \&$ Nethu Wickramasinghe ${ }^{1,2}$}

\author{
${ }^{1}$ Herpetological Foundation of Sri Lanka, 31/5, Alwis Town, Hendala, Wattala, Sri Lanka \\ ${ }^{2}$ Institute of Biochemistry, Molecular Biology, and Biotechnology, University of Colombo, Sri Lanka \\ ${ }^{3}$ Corresponding author.E-mail: mendi.w@ime.edu.lk/boiga2000@gmail.com
}

\begin{abstract}
A new species of the endemic scincid lizard genus Lankascincus from the Rakwana hills of Sri Lanka, is described. The new species is distinguished from its congeners by possessing the following combination of characters: maximum SVL less than $35.0 \mathrm{~mm}$, prefrontals in broad contact, seven supralabials, last supralabial scale split, 24 mid-body scale rows, 46-48 paravertebrals, 49-51 ventrals, 13-16 lamellae on fourth toe, and a conspicuous dark brown band from snout to mid-tail, gradually fading posteriad. The number of palpebral scales around eye is used as a meristic character in the genus Lankascincus for the first time.
\end{abstract}

Key words: Central highlands, rainforest, Ristella, South Asia, systematics, taxonomy

\section{Introduction}

The endemic Sri Lankan lizard genus Lankascincus Greer, 1991, is a widespread and an abundant group of litter skinks distributed throughout the island. In describing this new genus, Greer (1991) recognized six species, of which three were new: $L$. deraniyagalae, $L$. taylori, and L. gansi. The remaining three were new combinations previously allocated to Sphenomorphus: L. taprobanensis (Kelaart, 1854), L. fallax (Peters, 1860), and L. deignani (Taylor, 1950). Lankascincus fallax, which is also the most abundant and widely distributed member of the genus, was designated the type species (Greer 1991).

Four more species were added in 2007: two from the central highlands (Lankascincus munindradasai Wickramasinghe, Rodrigo, Dayawansa et al., 2007, and L. sripadensis Wickramasinghe, Rodrigo, Dayawansa et al., 2007), along with L. greeri Batuwita \& Pethiyagoda, 2007, and L. dorsicatenatus (Deraniyagala, 1953), the latter a new combination following the rediscovery of a paratype from the long-lost type series (Batuwita \& Pethiyagoda 2007).

The most recent comprehensive taxonomic review of Lankascincus by Batuwita (2019) recognized nine species [including the new combination Lankascincus megalops (Annandale, 1906), previously allocated to Sphenomorphus], while synonymising $L$. deraniyagalae with $L$. fallax, and $L$. munindradasai with L. taprobanensis. 
These small-sized, slender, terrestrial skinks are most closely related to the Indian genus Ristella Gray, 1839. Greer (1991) drew attention to the resemblance of the two genera, while Austin et al. (2004), based on molecular evidence, identified them as belonging to a distinct lineage. The molecular phylogeny of Pyron et al. (2013) showed Ristella to be the sister-group of Lankascincus, while Hedges (2014) included the two genera in a new family, Ristellidae, supported both by molecular and morphological evidence, and identifying a suite of familial autapomorphies.

Here we describe a further new species of Lankascincus, based on a series of specimens from the Rakwana hills, which were collected from Southern Province of Sri Lanka.

\section{Material and methods}

During field surveys carried out in 2007, we observed a Lankascincus population in Enasalwatte, Rakwana hills (Fig. 1). Four specimens were collected from this locality. These were photographed in life using a Canon EOS 40D, Canon 100mm F/2.8 IS USM macro lens, and Canon 580EX II Flash Lite. A tail snipping from the holotype were fixed in $96 \%$ ethanol for future DNA analysis. The entire series was euthanized prior to fixing in $15 \%$ formalin and subsequently transferred to $75 \%$ ethyl alcohol after one day.

The specimens were deposited in the National Museum of Sri Lanka, Colombo, Sri Lanka (NMSL) and the National Wildlife Research and Training Centre, Department of Wildlife Conservation, Girithale, Sri Lanka (DWC). Institutional abbreviations: Field Museum of Natural History, Chicago, USA (FMNH); Wildlife Heritage Trust, Sri Lanka (WHT); the Natural History Museum, London (BMNH); Smithsonian Institution National Museum of Natural History, Washington DC, USA (USNM); and the NMSL and DWC. Museum acronyms are those of Uetz et al. (2019).

Observations were made using a Leica M50 $(\times 10-40)$ microscope, on the left side of the specimens. The following measurements were taken to the nearest $0.1 \mathrm{~mm}$ with a Mitutoyo digital calliper (each measurement was taken three times and the mean recorded): snout-vent length (SVL, from tip of snout to anterior margin of vent), head length (HL, from posterior edge of the retro-articular process of the mandible to tip of snout), head width (HW, width of head at the temporo-mandibular articulation / angle of the jaws), head depth (HD, dorso-ventral distance between occiput and throat), snout length (ES, from anterior border of orbit to tip of snout), head width at front-eye (width of head at the anterior edge of the orbit), head width at back-eye (width of head at the posterior edge of the orbit), orbit diameter (ED, the greatest horizontal diameter of the orbit), nostril-snout length (from anterior border of nostril to tip of snout), internarial distance (shortest dorsal distance between inner margins of nares), eye-nostril length (from anterior border of orbit to the posterior border of nostril), tympanum-nostril length (from anterior border of tympanum to the posterior border of nostril), tympanum horizontal diameter (THD, greatest horizontal diameter of the tympanum), tympanum vertical diameter (greatest vertical diameter of the tympanum), tympanum-snout length (from anterior border of tympanum to tip of snout), tympanum-eye length (from posterior border of orbit to anterior border of tympanum), antebrachium length (on the dorsal surface from the posterior surface of the elbow while flexed 90 degree to the base of the palm), shank length (from the posterior surface of the knee while flexed 90 degree to the base of the heel), axillagroin length (AG, distance between axilla and groin), tail length (TAL, from tip of tail to posterior margin of vent), tail base width (TBW, greatest width at tail base), tail base depth (TBD, greatest depth at tail base), and total length ( $T L=$ SVL+TAL (from tip of snout to tip of tail).

Supralabial and infralabial scales were counted from the gape to the rostral and mental scales, respectively. Ventrals included all scales from the scale posterior to the postmental to the last scale bordering the vent, counted along the ventral midline; and subcaudals from the first scale bordering the vent up to the tail tip, counted along the subcaudal midline. Paravertebral scales were counted from the postparietal / nuchal to the level of the posterior margin of the thigh in a straight line immediately left of the vertebral column. Subdigital lamellae were counted from the first proximal enlarged lamella wider than the largest palm scale to the distal-most lamella at the base of the claw. Total number of longitudinal scale rows was counted around the midbody (AG/2, at half-length of axilla-groin length). Sex was determined by the throat colouration, and the presence or absence of hemipenes by illuminating the base of the tail. 


\section{Plate 09}

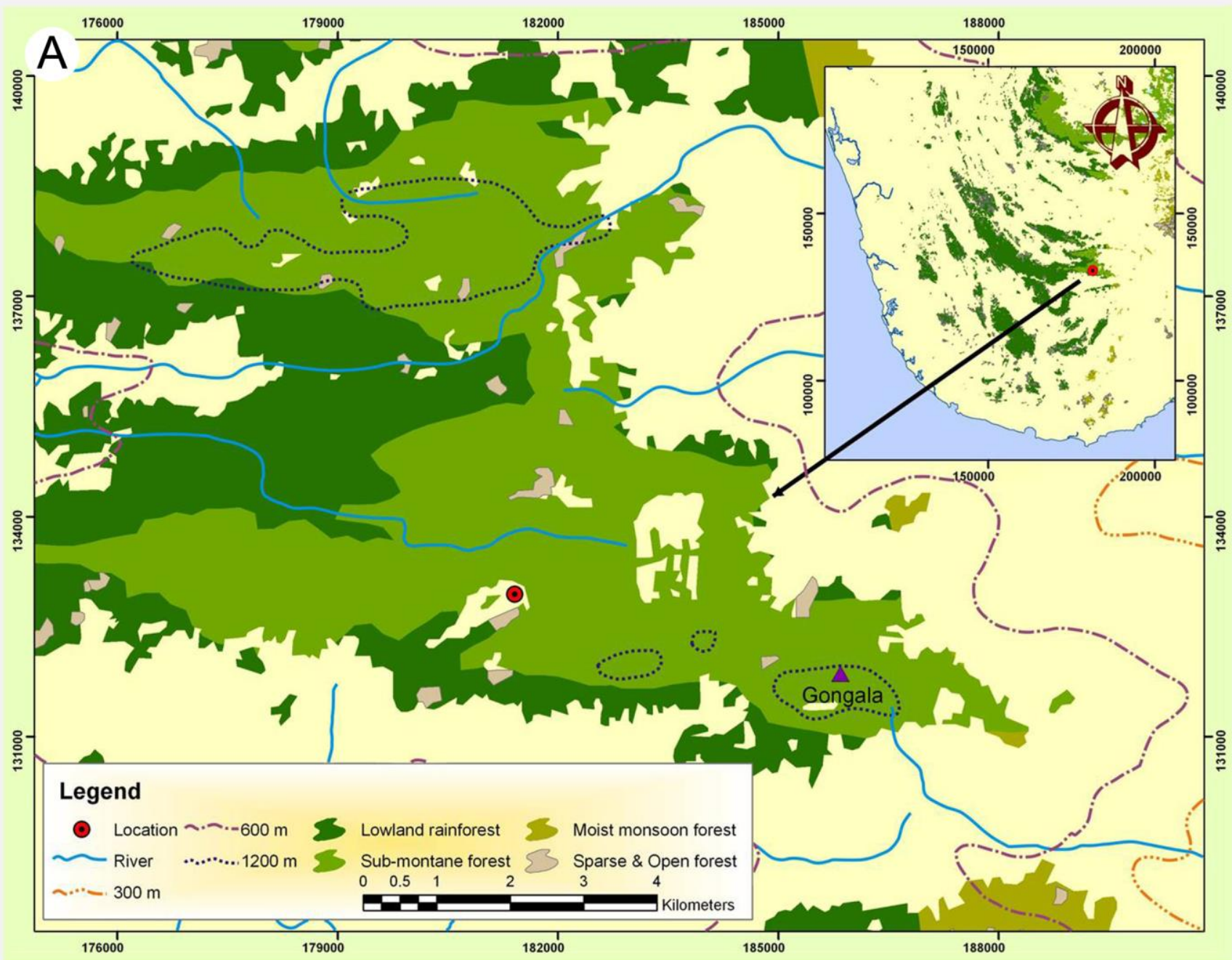

B

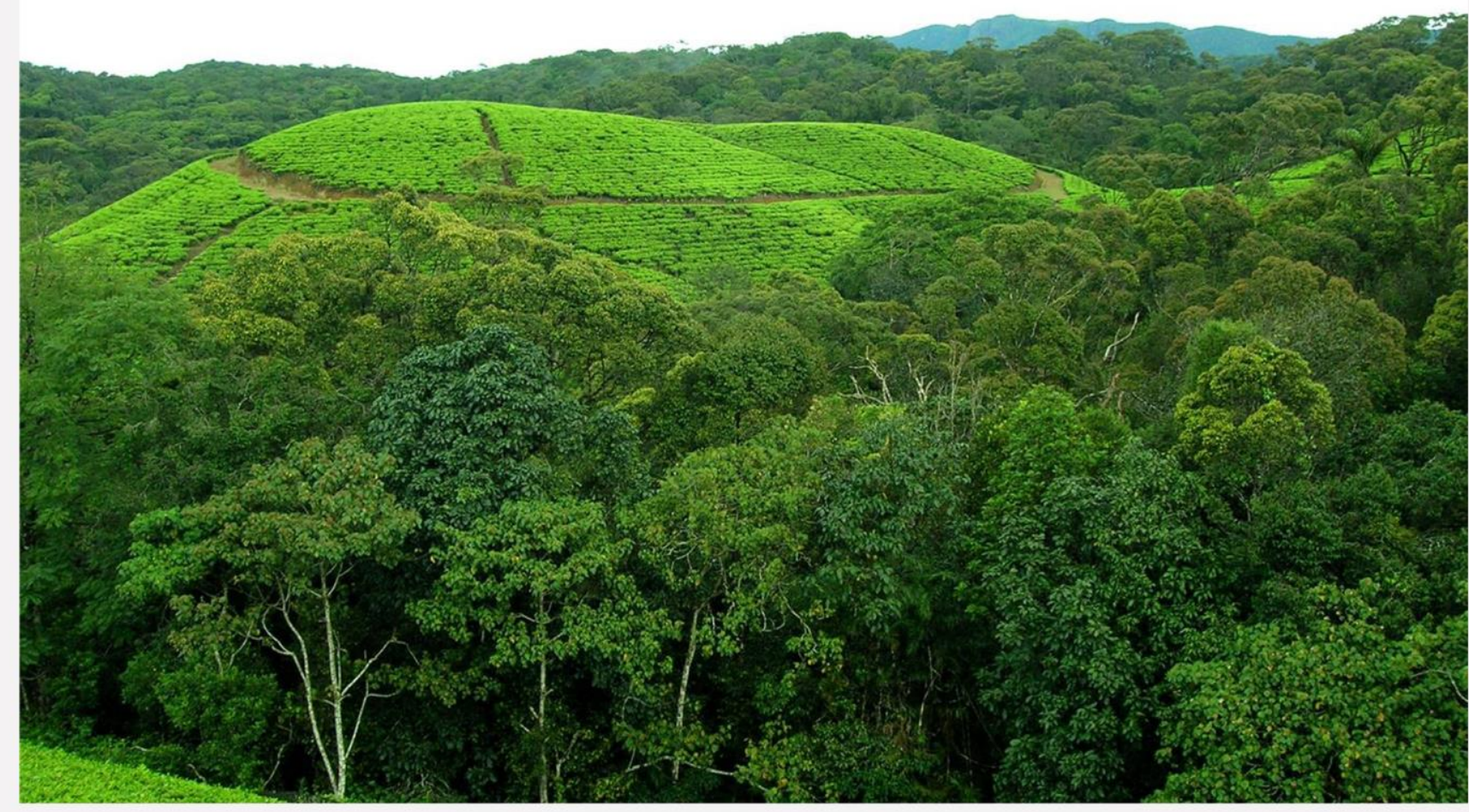

Figure 1. (A) Distribution map showing the type locality (Rakwana range) and (B) forest fragmentation in the type locality of Lankascincus merrill sp. nov. due to the encroachments by tea plantations. 


\section{Taxonomy}

Lankascincus merrill sp. nov.

(Figs. 1-5, Table 1)

Holotype. Adult male, NMSL 2011.01.01, SVL $34.9 \mathrm{~mm}$, collected from Enasalwatte Estate, Sinharaja Division (Army Camp Forest), Rakwana Hills, Matara District, Southern Province, Sri Lanka $\left(06^{\circ} 23^{\prime} \mathrm{N}, 080^{\circ} 36^{\prime} \mathrm{E}\right.$, alt. $1,040 \mathrm{~m}$ a.s.1.), by D.R. Vidanapathirana, N. Ranwella, and L.J.M. Wickramasinghe, on 25 November 2007.

Paratypes $(n=3)$. Adult females, NMSL 2011.01.02, SVL $33.7 \mathrm{~mm}$ and DWC 2011.05.02, SVL $34.0 \mathrm{~mm}$; adult male, DWC 2011.05.01, SVL $32.8 \mathrm{~mm}$; same locality as holotype; collected by D.R. Vidanapathirana and L.J.M. Wickramasinghe, on 28 December 2007.

Diagnosis. Lankascincus merrill sp. nov. is distinguished from its congeners by possessing the following combination of characters: maximum SVL 32.8-34.9 mm; prefrontals in contact; seven supralabials, the last one split; 24 mid-body scale rows; 46-48 paravertebrals; 4951 ventrals; $8-10$ and $13-16$ lamellae on fourth finger and fourth toe, respectively; and a conspicuous dark-brown band from snout to mid-tail, gradually fading posteriad.

Description of holotype. Male, head depressed (HD/HW ratio $0.71, \mathrm{HD} / \mathrm{HL}$ ratio 0.42 ), narrow (HW/HL ratio 0.59), distinct from neck; snout long (ES/HW ratio 0.55), greater than orbit diameter (ED/ES ratio 0.78); orbit wider than tympanum; ear aperture small (ED/THD ratio 4.2).

Rostral shield large, posterior margin convex; no supranasal or postnasal scale; frontonasal in contact with anterior loreal laterally (fused on left side); prefrontals in contact with posterior loreal laterally, supraciliary, $1^{\text {st }}$ supraocular and frontal posteriorly; frontal longer than frontonasal and prefrontal combined, shorter than frontoparietal and interparietal combined; supraoculars four, $2^{\text {nd }}$ widest in transverse axis, $3^{\text {rd }}$ longest in longitudinal axis, first two supraoculars in contact with frontal, $3^{\text {rd }}$ in contact with frontoparietal, $4^{\text {th }}$ in contact with frontoparietal, parietal, upper primary temporal and last supraciliaries; frontoparietals larger than interparietal; parietals large, touching each other behind interparietal, in contact with $4^{\text {th }}$ supraocular and primary temporals anteriorly, upper secondary temporal and dorso-nuchal scales posteriorly; nasal non-fused; loreals two; anterior loreal touching prefrontal, frontonasal, nasal, $1^{\text {st }}$ and $2^{\text {nd }}$ supralabials, and posterior loreal; posterior loreal larger than anterior loreal, longer on longitudinal axis, touching prefrontal, anterior loreal, $2^{\text {nd }}$ supralabial, two preoculars, and $1^{\text {st }}$ supraciliary; preoculars two, lower preocular larger, touching upper preocular, posterior loreal, $2^{\text {nd }}$ and $3^{\text {rd }}$ supralabials, $1^{\text {st }}$ subocular and palpebral scales; supraciliaries nine, placed between supraocular and upper palpebrals; upper palpebrals 17, placed between eye and supraciliary row; lower palpebrals 17, placed between eye and subocular row; suboculars ten, smaller than supralabials, touching $3^{\text {rd }}-6^{\text {th }}$ supralabials ventrally, lower postoculars and primary temporal scale posteriorly, last subocular touching lower and upper primary temporals, lower anterior and posterior postoculars; anterior postoculars two, upper one larger than lower; posterior postoculars three, larger than anterior postoculars, touching pretemporals and primary temporals; pretemporals two, lower one larger than upper, touching parietals, secondary temporals and primary temporals; primary temporals two, upper one larger, lower one touching $9^{\text {th }}$ and $10^{\text {th }}$ suboculars, $6^{\text {th }}$ and $7^{\text {th }}$ supralabials, upper one touching last uppersupralabial and secondary temporals; secondary temporals two, upper one longer than the lower, upper one touching parietal and upper tertiary temporal; tertiary temporals two, lower one larger, touching lower secondary temporal and upper posterior supralabials.

Supralabials 7, the last supralabial split, $5^{\text {th }}$ at mid-orbit point; post-supralabials two; mental wider than postmental in transverse axis, shorter in longitudinal axis, touching $1^{\text {st }}$ infralabial only; infralabials five, single post-infralabial; chinshields three pairs, first pair meeting in midline, first chinshield touching $1^{\text {st }}$ and $2^{\text {nd }}$ infralabials, second pair touching $2^{\text {nd }}$ and $3^{\text {rd }}$ infralabials, third pair separated from infralabial row by a single slender scale.

Body moderately elongate, body scales smooth; paravertebrals 47 ; ventrals 49 ; median preanals enlarged, outer preanals overlap inner preanals; fourth finger and fourth toe longer than others; fourth finger with nine smooth lamellae; fourth toe with 16 smooth lamellae; lamellae formulae for fingers and toes $4>3>5>2>1$ and $4>3>5>2>1$, scales of palm and foot elevated. 
Tail longer than body (TL/SVL ratio 1.4), round in cross section (TBD/TBW ratio 0.97 ); tail tip $(23.5 \mathrm{~mm})$ excised from original tail of $49.1 \mathrm{~mm}$; subcaudals 75 .

Variation. See Table 1.

Colouration. In life (Fig. 2A), body background light brown. Entire dorsum appearing striped due to irregular dark-brown markings on the light-brown background. Laterally a conspicuous dark-brown band from snout to mid-tail, gradually fading posteriad. Regions above and below this band golden brownish. Upper golden-brown region margined by a narrow dark-brown line dorsally. Lateral head and anterior body up to forelimb with white spots, irregularly arranged. Entire vent light brown, except throat and tail, which are darker; each scale on vent with a white spot, the spots connecting to give a striped appearance from neck to tip of tail.

After 13 years in preservative, colour slightly faded from dark brown to light brown, black to dark brown, and golden brown and light brown to off white. Ventral white spots indistinct.

Etymology. The specific epithet is a noun in apposition, honoring Mr. Merrill J. Fernando, founder of Dilmah and Dilmah Conservation, for his support of biodiversity conservation in Sri Lanka. Suggested vernacular names are

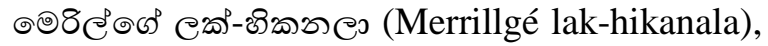
Merrillavin arené, and Merrill's Lanka-skink, in Sinhala, Tamil and English, respectively.

Table 1. Morphometric (in mm) and meristric character comparisons of holotype and paratypes of Lankascincus merrill sp. nov.

\begin{tabular}{|c|c|c|c|c|c|c|}
\hline \multirow[b]{3}{*}{ Character } & \multicolumn{6}{|c|}{ Lankascincus merrill sp. nov. } \\
\hline & \multicolumn{2}{|c|}{ male $(n=2)$} & \multicolumn{2}{|c|}{ female $(n=2)$} & \multirow[b]{2}{*}{$\begin{array}{c}\text { Mean } \pm S \\
\text { D }\end{array}$} & \multirow[b]{2}{*}{ Range } \\
\hline & $\begin{array}{c}\text { holotype } \\
\text { NMSL } \\
2011.01 .01\end{array}$ & $\begin{array}{c}\text { paratype } \\
\text { DWC } \\
2011.05 .01\end{array}$ & $\begin{array}{c}\text { paratype } \\
\text { NMSL } \\
2011.01 .02\end{array}$ & $\begin{array}{c}\text { paratype } \\
\text { DWC } \\
2011.05 .02\end{array}$ & & \\
\hline snout-vent length (SVL) & 34.9 & 32.8 & 33.7 & 34.0 & $33.9 \pm 0.9$ & $32.8-34.9$ \\
\hline head length (HL) & 8.3 & 7.5 & 7.4 & 7.2 & $7.6 \pm 0.5$ & $7.2-8.3$ \\
\hline head width (HW) & 4.9 & 4.7 & 4.7 & 4.5 & $4.7 \pm 0.2$ & $4.5-4.9$ \\
\hline head depth (HD) & 3.5 & 3.1 & 3.3 & 3.0 & $3.2 \pm 0.2$ & $3.0-3.5$ \\
\hline snout length (ES) & 2.7 & 2.4 & 2.4 & 2.5 & $2.5 \pm 0.2$ & $2.4-2.7$ \\
\hline head width at front-eye & 2.7 & 2.3 & 2.5 & 2.4 & $2.5 \pm 0.2$ & $2.3-2.7$ \\
\hline head width at back-eye & 3.9 & 3.6 & 3.7 & 3.8 & $3.7 \pm 0.1$ & $3.6-3.9$ \\
\hline orbit diameter (ED) & 2.1 & 1.9 & 2.0 & 2.0 & $2.0 \pm 0.1$ & $1.9-2.1$ \\
\hline nostril-snout length & 1.0 & 1.2 & 1.3 & 1.1 & $1.1 \pm 0.1$ & $1.1-1.3$ \\
\hline internarial distance & 1.4 & 1.6 & 1.5 & 1.6 & $1.5 \pm 0.1$ & $1.4-1.6$ \\
\hline eye-nostril length & 1.6 & 1.6 & 1.5 & 1.6 & $1.6 \pm 0.0$ & $1.5-1.6$ \\
\hline tympanum-nostril length & 6.1 & 5.5 & 5.8 & 5.6 & $5.8 \pm 0.3$ & $5.5-6.1$ \\
\hline tympanum horizontal diameter & 0.5 & 0.4 & 0.4 & 0.4 & $0.4 \pm 0.0$ & $0.4-0.5$ \\
\hline tympanum vertical diameter & 0.5 & 0.5 & 0.7 & 0.5 & $0.5 \pm 0.1$ & $0.5-0.7$ \\
\hline tympanum-snout length & 6.8 & 6.5 & 6.5 & 6.6 & $6.6 \pm 0.1$ & $6.5-6.8$ \\
\hline tympanum-eye length & 4.6 & 4.4 & 4.4 & 4.3 & $4.4 \pm 0.2$ & $4.3-4.6$ \\
\hline antebrachium length & 2.7 & 2.6 & 2.5 & 2.5 & $2.6 \pm 0.1$ & $2.5-2.7$ \\
\hline shank length & 3.8 & 3.7 & 3.8 & 3.7 & $3.7 \pm 0.1$ & $3.7-3.8$ \\
\hline axilla-groin length (AG) & 19.3 & 17.2 & 18.4 & 18.8 & $18.4 \pm 0.9$ & $17.2-19.3$ \\
\hline tail length (TAL) & 49.1 & 51.2 & 49.9 & 45.9 & $49.0 \pm 2.3$ & $45.9-51.2$ \\
\hline tail base width (TBW) & 4.1 & 3.5 & 4.0 & 3.8 & $3.9 \pm 0.3$ & $3.5-4.1$ \\
\hline tail base depth (TBD) & 4.0 & 3.4 & 3.9 & 3.6 & $3.7 \pm 0.2$ & $3.4-4.0$ \\
\hline supralabials & 7 & 7 & 7 & 7 & & 7 \\
\hline supralabials at mid orbit & 5 & 5 & 5 & 5 & & 5 \\
\hline infralabials & 5 & 5 & 5 & 5 & & 5 \\
\hline paravertebrals & 47 & 47 & 48 & 48 & & 47,48 \\
\hline scale rows at midbody & 24 & 24 & 24 & 24 & & 24 \\
\hline ventrals & 49 & 50 & 50 & 51 & & $49-51$ \\
\hline subcaudals & 75 & 84 & 82 & 79 & & $75-84$ \\
\hline lamellae on fingers $\mathrm{I}-\mathrm{V}$ & $\begin{array}{c}4,5,8,9 \\
6\end{array}$ & $\begin{array}{c}4,7,8,9 \\
6\end{array}$ & $\begin{array}{c}4,6,7,8 \\
5\end{array}$ & $\begin{array}{c}4,6,8,10 \\
6\end{array}$ & & \\
\hline lamellae on toes $\mathrm{I}-\mathrm{V}$ & $\begin{array}{c}5,9,12 \\
16,10\end{array}$ & $\begin{array}{c}5,9,12 \\
14,9\end{array}$ & $\begin{array}{c}5,9,11 \\
13,10\end{array}$ & $\begin{array}{c}5,8,12 \\
14,8\end{array}$ & & \\
\hline
\end{tabular}




\section{Plate 10}
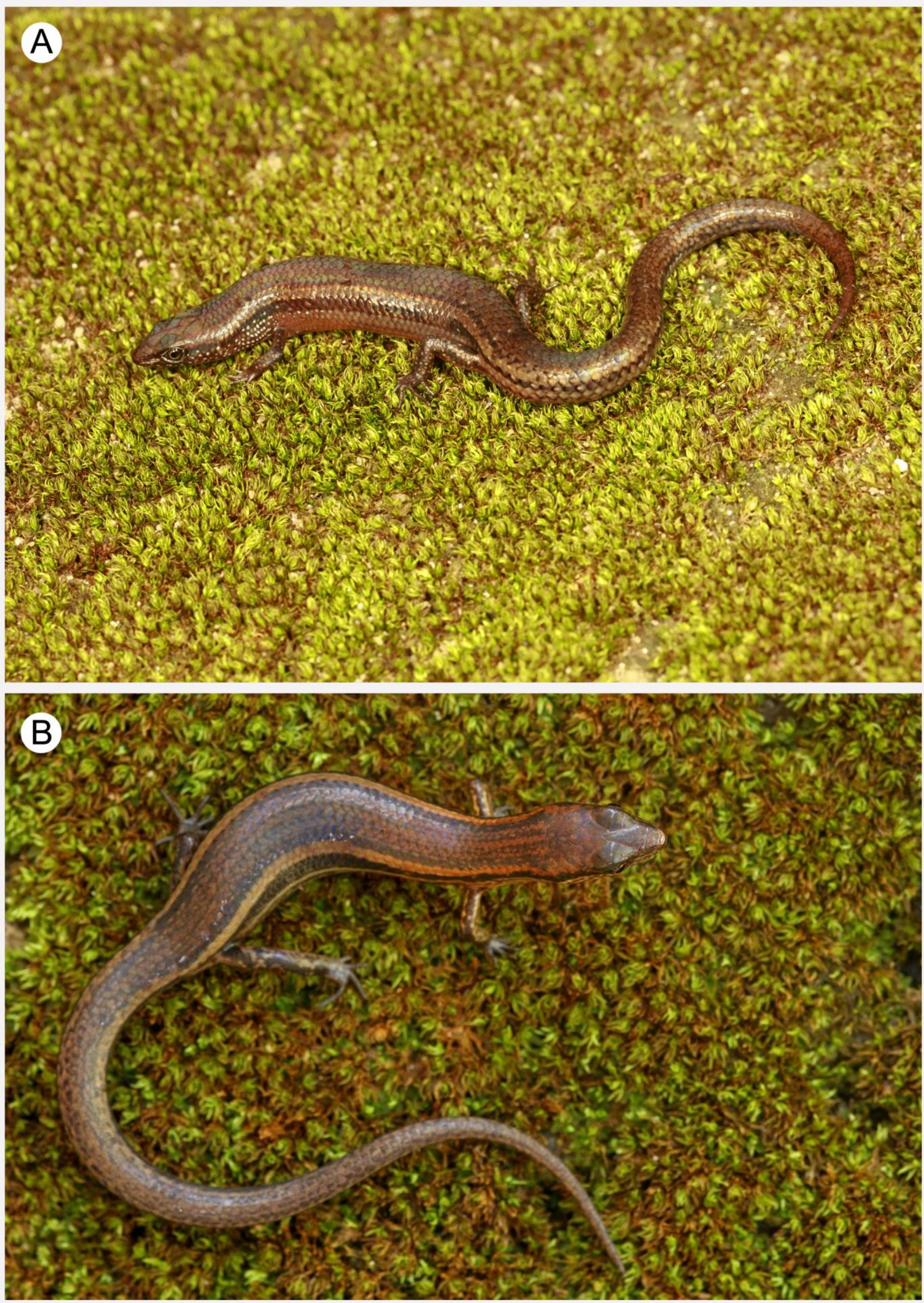

Figure 2. Full body of Lankascincus merrill sp. nov., (A) holotype (male, NMSL 2011.01.01) in dorsolateral view and (B) paratype (female, NMSL 2011.01.02) in dorsal view. 


\section{Plate 11}

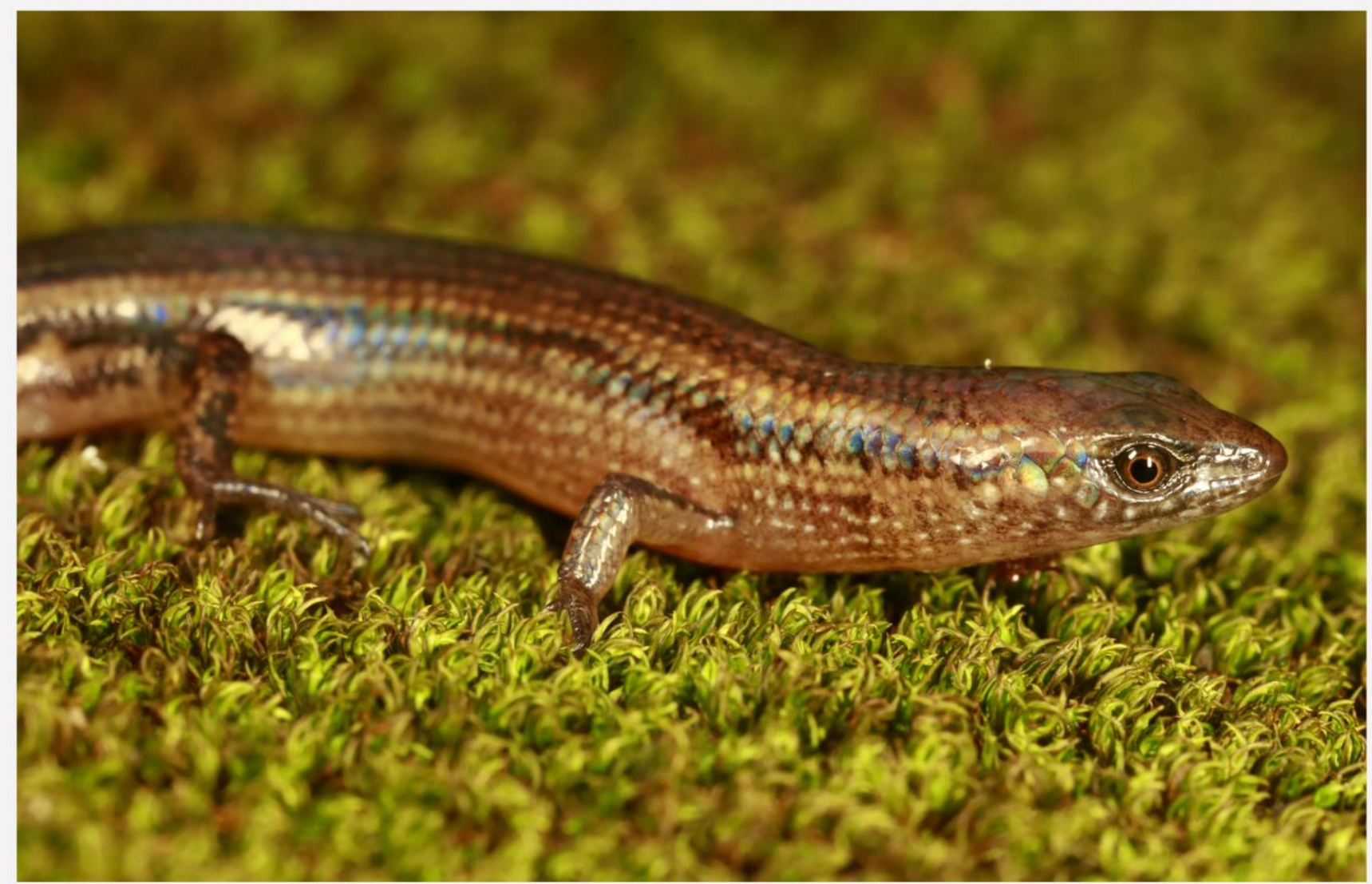

Figure 3. Anterior body of Lankascincus merrill sp. nov. holotype (NMSL 2011.01.01) in lateral view

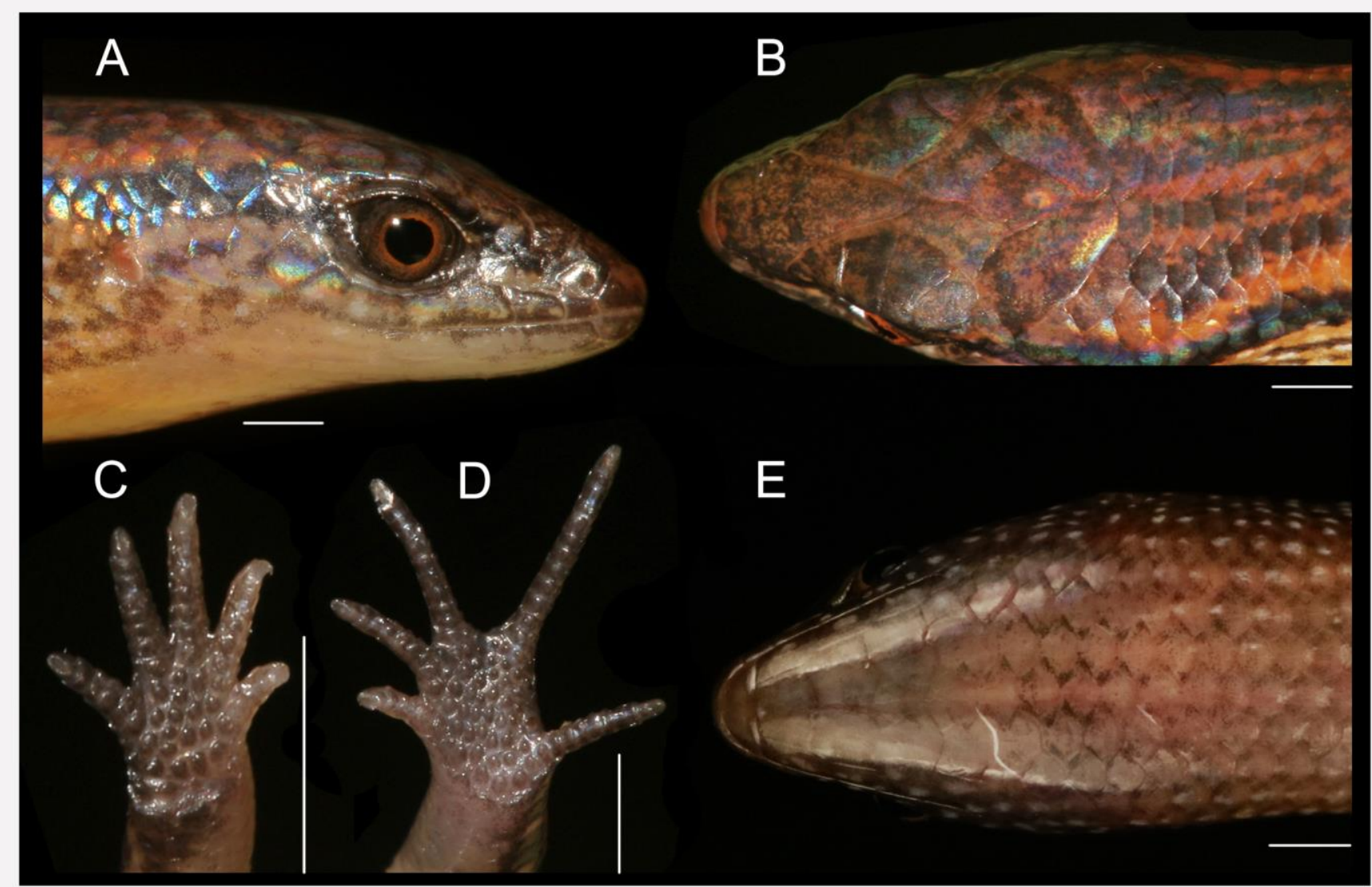

Figure 4. Lankascincus merrill sp. nov. paratype (NMSL 2011.01.02) head in (A) lateral view, (B) dorsal view; and ventral view of the (C) palm, (D) foot; holotype (NMSL 2011.01.01) head in (E) ventral view; scale: $1 \mathrm{~mm}$. 

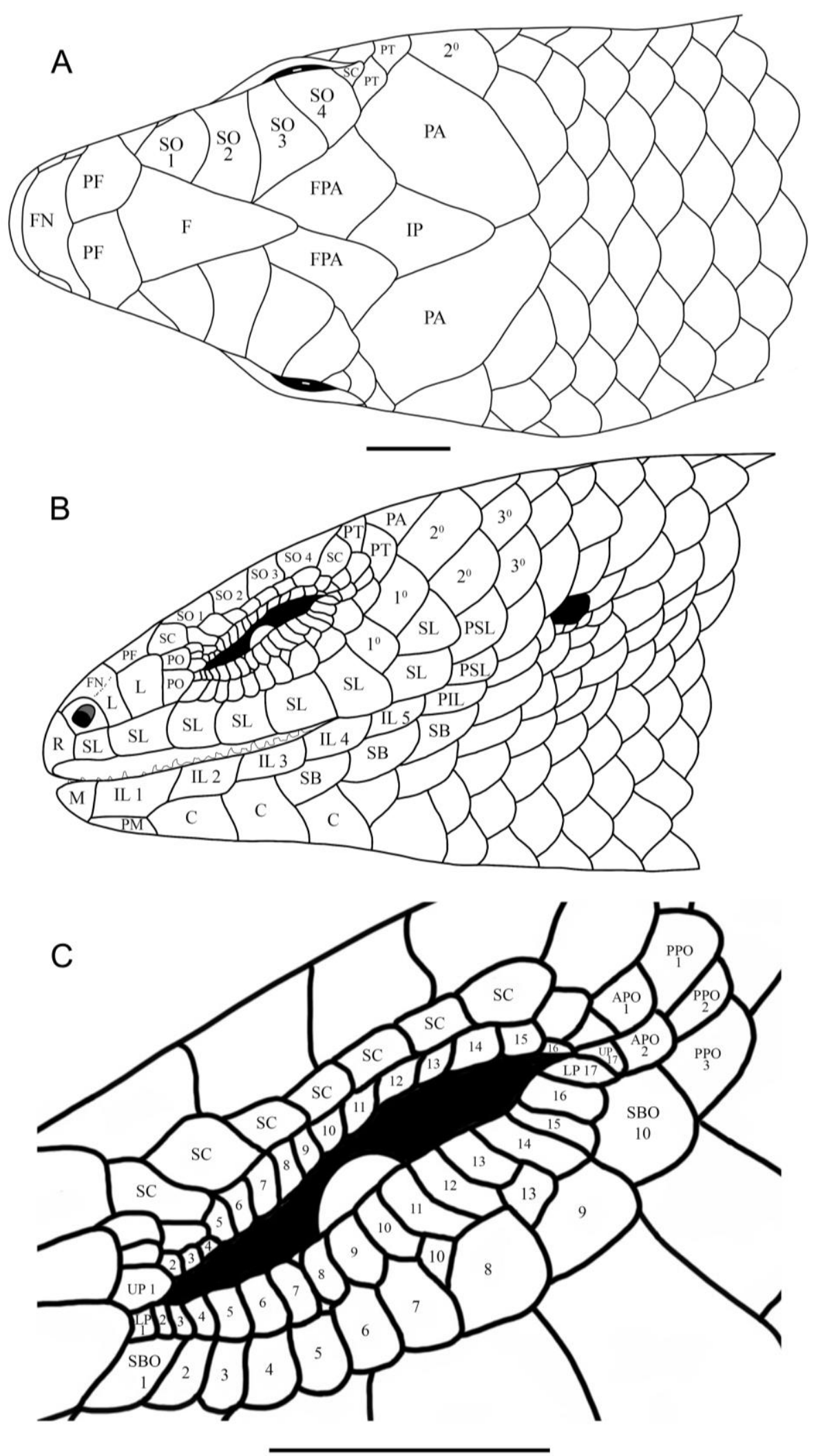

Figure 5. Head scalation and terminology in (A) dorsal and (B) lateral views of the holotype of Lankascincus merrill sp. nov. and (C) shows a close-up of palprebal scales around eye. $\mathbf{1}^{\circ}$, primary temporal; $\mathbf{2}^{\circ}$, secondary temporal; $\mathbf{3}^{\circ}$, tertiary temporal; APO, anterior postocular; C, chinshield; F, frontal; FN, frontonasal; FPA, frontoparietal; IL, infralabial; IP, interparietal; L, loreal; LP, lower palpebral; M, mental; PA, parietal; PF, prefrontal; PIL, post infralabial; PM, postmental; PO, preocular; PPO, posterior postocular; PSL, posterior supralabial; PT, pretemporal; R, rostral; SB, sublabial; SBO, subocular; SC, supraciliary; SIL, sublabial; SL, Supralabial; SO, supraocular; UP, upper palpebral; scale $1 \mathrm{~mm}$. 
Sexual dichromaticism. Based on the female paratype (NMSL 2011.01.02) in life (Fig. 2B), the dorsal and lateral body colour pattern the same as the male but with a darker tinge, where the conspicuous dark-brown line is black and all light-brown regions are dark brown. White spots entirely absent on body. The entire venter off-white, with no white spots.

Comparison. Male specimens of Lankascincus merrill sp. nov. superficially most closely resemble female L. fallax (Peters, 1860), sharing an overall similar body colouration and exhibiting a conspicuous dark-brown lateral band from snout to mid-tail. However, the new species differs from L. fallax in having two frontoparietals ( $v s$ one), the last supralabial split (vs single), and in being smaller: maximum SVL $35.0 \mathrm{~mm}$ ( $v s$ 40.0-44.0 mm). The new species has similar or overlapping scale counts with those of $L$. gansi. However, the new species differs from $L$. gansi in having 24 scale rows at midbody ( vs 26-28); 79-84 subcaudals ( vs 5462); and a longer tail, TAL/SVL, 1.44 (vs shorter 1.11).

The new species differs from its congeners in having a smaller adult body size, with maximum SVL $35.0 \mathrm{~mm}$ ( $v s 40.0 \mathrm{~mm}$ ), and it is further distinguished from Lankascincus deignani and $L$. greeri by having 24 scale rows at midbody ( $v s$ 26-28), last supralabial scale split ( $v s$ single), and 13-16 lamellae on fourth toe (vs 22); from $L$. dorsicatenatus and $L$. megalops by having 24 scale rows at midbody (vs 28), and 13-16 lamellae on fourth toe (vs 17-18); from L. sripadensis by the last supralabial split ( $v s$ single), 24 scale rows at midbody ( $v s$ 26), 46-48 paravertebrals ( $v s$ 5658), 50-51 ventrals (vs 56-58), 13-16 lamellae on fourth toe (17-19); from $L$. taprobanensis by prefrontals in contact ( $v s$ widely separated), 7 supralabials with $5^{\text {th }}$ at mid-orbit position and last supralabial split ( $v s \quad 6$ supralabials, $4^{\text {th }}$ at mid-orbit position and last supralabial single), 46-48 paravertebrals (vs 57-62), 24 scale rows at midbody (vs 26-28), 50-51 ventrals (vs 5658 ); and from $L$. taylori by having the last supralabial split (vs single), 46-48 paravertebrals (vs 52-53), 24 scale rows at midbody (vs. 26-28), and 50-51 ventrals (vs 5658).

Natural history. Lankascincus merrill is diurnal, occurring in pairs, and can be commonly found in shady areas under thick leaf litter in drainage ditches and under rock crevices in tea plantations, as well in forests with substantial canopy cover, beneath thick $(\sim 10$ $\mathrm{cm})$ leaf litter, and under logs. They were also seen basking on leaf litter, and on small rocks occurring among leaf litter, after a heavy shower of rain. They lay two eggs at a time, beneath leaf litter and under logs in forests.

\section{Discussion}

The number of palpebral scales around the eye was used as a meristic character of genus Lankascincus for the first time. The term 'palpebral scale' was previously used by Neang et al. (2018) for skinks in the genus Scincella Mittleman, 1950. The family Ristellidae was defined by Hedges (2014), with a combination of diagnostic characters unique to both Ristella and Lankascincus, while pointing out that the former has retractile claws, unlike other skink genera, while noting "claw condition not yet determined in Lankaskincus". All members of Lankascincus, however, possess non-retractile claws and differ from Ristella also in possessing five fingers ( $v s 4$ ).

Based on the four specimens measured by us, Lankascincus merrill sp. nov. has the smallest SVL among the species in the genus. The new species was found in the elevation range 950-1,100 m a.s.l., in the Rakwana hills. The species was found to be syntopic with both $L$. gansi and L. fallax. While both the new species and $L$. gansi are distributed in natural as well as disturbed forests, L. fallax is found only in disturbed areas near forest edges. Despite its widespread distribution, from the lowland wet zone to the sub-montane rain forests of the Central Highlands, Sinharaja, and the Rakwana massif, $L$. merrill is syntopic with $L$. gansi only in the Rakwana hills. Despite sharing similar habitat and characteristics, the new species is readily distinguished from $L$. fallax by its meristic characteristics and from $L$. gansi by its colouration.

\section{Acknowledgments}

We thank the Department of Wildlife Conservation, particularly M.G.C. Sooriyabandara and L. Peiris, for permission (Ref. WL/3/3/354) and the Forest Department, particularly W.A.C. Weragoda, N.D.R. Weerawardena, I. Alawatte, and K. Bandara, for permission (Ref. R\&E/RES/NFSRCM/2018-02) to survey lands in their care. We thank P. Samarawickrama for preparing the map, M. 
Chathuranga assisted in editing the photographs and A. Wahid, S. Weerasinghe for assistance in the field. We also thank our colleagues at Herpetological Foundation of Sri Lanka; the Institute of Biochemistry Molecular Biology and Biotechnology (IBMBB) for numerous courtesies; and A. Abayakoon for his continuing support. For hospitality during a research visit to the BMNH, the first author thanks D.J. Gower, P. Campbell, M. Wilkinson, and R. Rodrigo, and to the FMNH, Chicago, A. Resetar. The Nagao Natural Environment Foundation provided partial funding for this work, K. Gunawardena and Canon Metropolitan provided camera equipment, and A. Perera designed a light source "FixIt" for the microscope. C. Bambaradeniya, C. Siler and R. Pethiyagoda (Ichthyology Section, Australian Museum) are acknowledged for critical comments on the initial draft of the manuscript, which undoubtedly improved the quality of the paper. J. Hallermann (Universität Hamburg, Germany), K. Ukuwela (Rajarata University of Sri Lanka), A.A.T. Amarasinghe (University of Indonesia), P. Bowles (IUCN), and an anonymous reviewer are acknowledged for valuable commentary. Finally, we thank our Principal Sponsor, Dilmah Conservation, for funding this project.

\section{Literature cited}

Annandale, A. (1906). New and interesting lizards in Colombo museum. Spolia Zeylanica, 3: 189-192.

Austin, C.C., I. Das and A. de Silva (2004). Higher-level molecular phylogenetic relationships of the endemic genus Lankascincus from Sri Lanka based on nuclear DNA sequences. Lyriocephalus, 5 (1 \& 2): 11-22.

Batuwita, S. (2019). A Review of the Lizards of the Endemic Genus Lankascincus (Reptilia: Scincidae: Lygosominae) from Sri Lanka. Bulletin of the Museum of Comparative Zoology, 162 (3): 211-262.

Batuwita, S. and R. Pethiyagoda (2007). Description of a new species of Sri Lankan litter skink (Squamata: Scincidae). Ceylon Journal of Science (Biological Sciences), 36 (2): 80-87.
Deraniyagala, P.E.P. (1953). A coloured atlas of some vertebrates from Ceylon: Vol. 2. Tetrapod Reptilia. The Ceylon Government Press: $100 \mathrm{pp}$.

Greer, A.E. (1991). Lankascincus, a new genus of skink lizards from Sri Lanka, with description of three new species. Journal of Herpetology, 25 (1): 59-64.

Hedges, S.B. (2014). The high-level classification of skinks (Reptilia, Squamata, Scincomorpha). Zootaxa, 3765 (4): 317-338.

Kelaart, E.H. (1854). Descriptions of new species of Ceylon Reptiles. Annals and Magazine of Natural History, 13: 407-408.

Peters, W.C.H. (1860). Über einige interessante Amphibien, welche von dem durch seine zoologischen Schriften rühmlichst bekannten österreichischen Naturforscher Professor Schmarda während seiner auf mehrere Welttheile ausgedehnten, besonders auf wirbellose Thiere gerichtet. Monatsberichte der Königlichen Akademie der Wissenschaften, Berlin (April): 182-186.

Pyron, R.A., F.T. Burbrink, and J.J. Wiens (2013). A phylogeny and revised classification of Squamata, including 4161 species of lizards and snakes. BMC Evolutionary Biology, 13 (93): $1-53$.

Taylor, E.H. (1950). Ceylon lizards of the family Scincidae. The University of Kansas Science Bulletin, 33 (2): 481-518.

Neang, T., S. Chan, and N.A. Poyarkov Jr. (2018). A new species of smooth skink (Squamata: Scincidae: Scincella) from Cambodia. Zoological Research, 39 (3): 214-233.

Uetz P., S. Cherikh, G. Shea, I. Ineich, P.D. Campbell et al. (2019). A global catalog of primary reptile type specimens. Zootaxa, 4695 (5): $438-450$

Wickramasinghe, L.J.M., R. Rodrigo, N. Dayawansa, and U.L.D. Jayantha (2007). Two new species of Lankascincus (Squamata: Scincidae) from Sripada Sanctuary (Peak Wilderness) in Sri Lanka. Zootaxa, 1612: 124. 
Appendix I. Other specimens examined

Lankascincus deignani (4 ex.): Sri Lanka: USMN 120326 (holotype); Kekuna ella, Sinharaja forest: NMSL 2008.02.01-03.

L. dorsicatenatus (3 ex.): Sri Lanka: Rammalkada: NMSL uncat. (paratype); Batatombelena: WHT 6619; Kottawa, Galle: NMSL uncat. (WHT).

L. fallax (8 ex.): Sri Lanka: Kandahena Estate: WHT 1579; Puwakpitiya, Knuckles: WHT 2055; Awisawella Rest house: WHT 2207a-b; Kumaradola: WHT 6724; Punduloya: BMNH 95.7.23.28c (holotype of $L$. deraniyagalae), 95.7.23.28d-e (paratypes of $L$. deraniyagalae).

L. gansi (8 ex.): Sri Lanka: Haycoch, Hiniduma: WHT 151; Morningside: WHT 1519, 6720; Sinharaja: WHT 2208, 6722; Dediyagala forest reserve: WHT 6664; Nawinna, Galle: WHT 6671; Koskulana, Panapola: WHT 6723.

L. greeri (1 ex.): Sri Lanka: Kombala-Kottawa Forest Reserve: WHT 6524 (holotype).

L. sripadensis (16 ex.): Sri Lanka: Sripada Sanctuary (Adam's peak): NMSL 2007.05.001 (holotype), 2007.05.002-003 (paratypes), WHT 7503; Nanuoya: FMNH 131355-131361; Dimbula Patana: WHT 6567; Agra Arboretam WHT 6631, 6686, 6726; Balangoda road, Bogawanthalawa: WHT 6739.

L. taprobanensis (19 ex.): Sri Lanka: BMNH 1946.8.26.1 (syntype), 1946.8.3.20-21 (syntypes). Horton plains National Park: NMSL 2007.22.01-03, WHT 2014, 2096a-b, 2097a-b; Namunukula: WHT 1509; Thangamalai plains, Haputale: WHT 1927; Fishing Hut: WHT 2015a-d; Sripada Sanctuary (Adam's peak): NMSL 2007.21.01 (holotype of L. munindradasai), 2007.21.02 (paratype of $L$. munindradasai).

L. taylori (10 ex.): Sri Lanka: BMNH 72.3.23.4a (holotype), 72.3.23.4b-c (paratypes), FMNH 1070310; Gammaduwa: 1973.3.15 (paratype); Meda Mahanuwara: FMNH 167018 and 167035 (paratypes); Gannoruwa, Kandy: NMSL 2007.2.3.01-03. 